Measuring Vitality of the Ottoman Public Space in Kosovo Cities

Authors: $\quad$ Bujar Q. Bajçinovci, llir Gjinolli , Rron Beqiri

Submitted:

Published:

11. April 2018

Volume:

Issue:

Affiliation:

Languages:

Keywords:

26. April 2018

5

4

University of Prishtina, Faculty of Civil Engineering and Architecture, Kosovo

Albanian

Public Space, Public life, vitality Ottoman Squares, Ottoman bazaars.

DOI: $\quad$ 10.17160/josha.5.4.417

Journal of Science,

Humanities and Arts

JOSHA is a service that helps scholars, researchers, and students discover, use, and build upon a wide range of content 


\title{
Measuring Vitality of the Ottoman Public Space in Kosovo Cities
}

\author{
Ilir Gjinolli', Rron Beqiri', Bujar Bajçinovci" ${ }^{* 1}$ \\ ${ }^{1}$ University of Prishtina, Faculty of Civil Engineering and Architecture, Kosovo. \\ Email: Ilir.giinolli@gmail.com; ”bujar.bajcinovci@uni-pr.edu
}

\begin{abstract}
This paper elaborates the vitality of the ottoman public spaces in Kosovo Cities, generated by the public sphere of the contemporary city life. It analyses the public life in the main public space in four cities in Kosovo related to:

- Urban morphology - the structure and the position in the city, which relates also to content and history;

- $\quad$ Time dimension - historical background and their usability and vitality today;

- Functional dimension - the main content that triggers the public life in the public spaces.

In this research a combined research methodology/strategy involving case study research method and interpretative historical research was applied. Searching the history of development of the public space in the Kosovo cities, the basic arguments are found in the literature and archive documents, as well as extensive field survey of the public life. The results of the case study analyses show that, although they had been transformed from their original settings, the vitality of the ottoman public space of the same typology could be considered at a very high level.
\end{abstract}

Keywords: Public Space, Public life, vitality Ottoman Squares, Ottoman bazaars.

\section{INTRODUCTION}

Public life occurs in urban public spaces in a complex set of forms and functions; accordingly, these spaces must be capable to contain diverse behaviour, uses and activities such as walking, shopping, conversation, using the facilities to entertain, relax or even passing the time as daily activities, and also periodic festivities and events. Montgomery ${ }^{1}$,in his paper 'Making a city: Urbanity, vitality and urban design'(1998) explains that, "it is the public realm and associated semi-public spaces which provide the terrain for social interaction and a significant part of a city's transaction base, i.e. the market square, the street vendor, the shop frontage and the sidewalk café". Francis Tibbalds ${ }^{2}$ describes the public realm as, "all parts of the urban fabric to which the public have physical and visual access". Jan Gehl ${ }^{3}$ suggests that there are three main

\footnotetext{
${ }^{1}$ Montgomery, J. (1998) Making a city: urbanity, vitality and urban design. Journal of Urban Design, 3: 1, 93-116.

${ }^{2}$ Tibbald, F, (1992) Making People-Friendly Towns, Longman Group, London, 1992

${ }^{3}$ Gehl, J. (2011) Life between buildings, Island Press, Washington, 2011
} 
type of activities: necessary activities include those that are more or less compulsory (going to school or to work, shopping, waiting for a bus or a person), Optional activities (pursued if there is a wish to do so and if time and place make it possible) and social activities - activities that depend on the presence of others in public spaces. Vitality deals to the degree with which an urban space is socially successful. Vitality in the urban realm is an important quality because it reduces crime, makes commercial interests more viable, increases passive enjoyment of streetscape - people watching, encourages social regarded as an important measure of its health. ${ }^{4}$ Kevin Lynch ${ }^{5}$, identifies vitality as one of the performance dimension of urban design and describes it as the degree to which the form of places supports the functions, biological requirements and capabilities of human beings. In Montgomery's definition (1998), it refers to the number of people in and around the street (pedestrian flows) acrosstimes of the day and night, the uptake of facilities, the number of cultural events and celebrationsover the year, the presence of an active street life, and generally the extent to which a place feels alive or lively. This paper explores the socio-spatial relations of ottoman public spaces in Kosovo. It tends to show how the physical form and the functions that they accommodate, influences the pattern of use and behaviorin thepublic space.

\section{OTTOMAN PUBLIC SPACES}

The morphological feature of the Ottoman city is characterized by the divison into two parts: the city centre where economic, religious, cultural and other civic activities took place and the residential areas - a number of 'mahalles'or residential neighbourhoods which comprised more private life of the residents. The morphological structure was bounded by a street network with mainly two types of streets - wider in the city centre and narrow streets and alleys - dead end streets/ coul-de-sacs for local use. As in all 'eastern cities', it is difficult to trace a hierarchy of the streets.

The main device of Ottoman city-making was the külliye. ${ }^{6}$ The word derives from the Arabic word meaning "the whole". It consisted of an interrelated group of buildings round a mosque installed and endowed bythe Sultan as the public nexus of obedient subjects, i.e. population. It is to be distinguished from the administrative centre of the town, usually a citadel, and the commercial centre of bazaars andhatts, which were placed next to the Friday mosque. In Kosovo we could trace these külliyes at least in four cities including Prishtina, Prizren, Gjakova and Peja.

\footnotetext{
${ }^{4}$ Jalaladdini, S. and Oktay, D.(2011) Urban Public Spaces and Vitality:A Socio-Spatial Analysis in the Streets of Cypriot Towns, Procedia Social and Behavioral Sciences 35 ( 2012 ) $664-674$ (2011)

${ }^{5}$ Lynch, K. (1961) The image of the city. Cambridge: Harvard University Press.

${ }^{6}$ Kostof, S. (1995) A history of Architecture, Settings and Rituals, Second Edition, Oxford University Press, USA
} 


\section{Squares}

The public spaces of the old Balkan town were distributed throughout the urban fabric of the bazaar in the mahalles. The network of these spaces was not planned, so we can assume that they occurred spontaneously. Observing them in the existing fabric and based on the surveyed material, we could consider that the open spaces usually occur at the crossings. Some time they occur alongside the streets and at the end of the cul-de-sacs. ${ }^{7}$ The role of the main square was taken by the marketplace, where coffeehouses, han's and caravanserais, hammam's, mosques and bedestans, constituted the physical and social settings, which was already discussed in the chapter of the Ottoman city structure. In terms of the shape, BranislavKojic, argues that it is diverse and irregular but among these various forms triangular plan can be distinguished in most of the cases. It was usually created in a street "Y" shaped junction of two or more branches of a street with a many combination of cuts and corners altering the shape of the triangular square.

\section{Bazaar / Çarshia}

The core area of the centre was the bazaar or çarşi in Turkish, a commercial area consisting ofbedesten (covered market), hans and caravanserais, shops where crafts, trade and other transactions were carried out. These buildings belonged to waqfs and provided the larger part of the urban commercial facilities. Because such buildings were rented by waqfs to merchants and artisans, the waqf system was directly related to urban economic activity. ${ }^{8}$ The shops and buildings allowed for each craft or business to occupy an opening on to the high street (uzuncarshi). The other buildings in the city centre were organized around the high street. For example, bazaars in Prishtina, Prizren, Peja and Gjakova, were also situated at the centre of the city. ${ }^{9}$

\section{Ottoman Gardens}

Mesire, the picnic and open-air grounds, called also çayir- (green meadow) are the real core of open-air system in the Ottoman city. They were very widespread in the 16th -18th century. EvliyaÇelebi mentioned the promenades of Berat, Prizren, and Shkoder with promenades along the river or Lake Shkodra. The traditional sociability and friendliness in the Ottoman city was a synonymous of country outing including entire families and groups of friends that socialized in a particular space enjoying food, spirits and generally having a fun and relaxing time.

\footnotetext{
${ }^{7}$ Kojic, Dj. B, (1976) StariBalkanskiGradovi, VarošiiVarošice, IAUS, Beograd, Serbia

${ }^{8}$ Shkodra, Z. (1973) EsnafetShqiptare (Albanian Guilds), Institute of History, Academy of Science of Albania, Tirana

${ }^{9}$ Acun Fatma, A portrait of the Ottoman Cities, Muslim Worls 92, no 3/4 Fall 2002, The H.W Wilson Comany
} 
The open-air coffeehouses under a pergola, on a wooden veranda or under an old tree, or at a particularly beautiful meadow, were sort of resembling the European Squares. The attractions such as wrestling, cirit (an equestrian game), and shadow theatres could be found in these spaces as well. ${ }^{10}$

How is the mesire formed? In the most important cases, there was an appropriation of the natural features of the place in the meadows and its waters, or the context of the place, including its panorama. In the majority of cases the transformation process of spaces was gradual. Some of these green areas could be found even nowadays like Marash park, along Lumbardhi river in Prizren that connects to the city with mountains through the valley and the gorge.

Taukbahce ('chicken garden'-in Turkish) park in Prishtina could be considered a mesire. Earlier Taukbahce use to be on the outskirts of the city and it was connected to the natural park of Germia through Vellusha stream valley. Stretching along a stream, Taukbahce has been for a long time a sanctuary for the citizens of Prishtina during the sping, fall and particularly during the hot summer days.

In Karagaç, Peja's natural park has been reconstructed after the world war II to include the manmade pond and a swimming pool. Later during the 60's, a camp and a restaurant have been added. The word Karagaç-'karaagaç' comes from Turkish for elm tree - a tall tree used very often in the ottoman gardens. In this paper case study method was used to analyse real-life context of the ottoman public space in Kosovo cities. Multiple cases were chosen due to the historic research on social context and different settings in the long period of Ottoman rule in Kosovo. Real life context here means the public life in a particular site, in particular time during a day, particular days in the week and seasons.

We used case study method to explain some causal links of transformations and current standings of public spaces in Kosovo cities. The multiple cases chosen in this research provide multiple sources of evidence and data which are compared inPrishitna, Prizren, Gjakova and Peja, the oldest cities in Kosovo, with a relatively preserved Ottoman core which provide the 'ground' facts for research.

The Typologies of the ottoman public spaces analysed in this research may differ slightly from what the definitions in the literature might suggest. The basic types chosen aresquare, bazaar and ottoman gardens.

\footnotetext{
${ }^{10}$ Cerasi, Maurice M. "Open Space, Water and Trees in Ottoman Urban Culture in the XVIIIth - XIXth Centuries." In Environmental Design: Journal of the Islamic Environmental Design Research Centre 2, edited by AttiloPetruccioli, 36-50. Rome: Carucci Editions, 1985
} 
- Public life survey

"...Please look closely at real cities. While you are looking, you might as well also listen, linger and think about what you see."- Jane Jacobs ${ }^{11}$

Direct observation is the primary tool of studying the public life studies. The users of public space were not directly involved in the survey, but their activity and behaviour were observed and mapped in order to understand how the space is used. The choice of tools is based on the features that make chosen public spaces samples for finding answers to the research questions. For any area/site study, it is necessary to consider the study context holistically, including physical, cultural and climate aspects. A single tool is rarely sufficient, it is rather usually necessary to combine various types of investigation.

\section{- Choosing the proper time, day and weather}

Usually this issue depends on the purpose of the study and local conditions. In order to cover the different time periods in a day, the survey took place from 10.00 to 16.00 and from 18.00 to 21.00. Counting took place 15 minutes each hour. It is considered that 15 minutes observation and counting during the hour could sufficiently illustrate the social life and activities in the public space in order to see the daily differences, the research was carried out during weekdays and weekends. What makes a public space a pleasant place to be and to use? The 16 quality criteria, based on JanGehl methodology ${ }^{12}$ on public life study, was used to evaluate the qualities that make a place that invite peoples to come and stay. These 16 criteria reflect mainly functional and social dimension of public space including aesthetic qualities and management dimension.

\section{ANALYSES OF OTTOMAN PUBLIC SPACES IN KOSOVO SHADERVAN - (The Fountain Square) - Prizren}

The Fountain Square - or 'Shadervan' in Prizren presents foci of public life with a long history, dating back to 16-17 century in the Ottoman Empire. Originally it was smaller square a place where several old bazaar streets terminate and meet each other, which has been transformed in the beginning of $20^{\text {th }}$ century. Through the century the artisans guilds of Prizren - so called esnafsmaintained the tradition of meeting at the 'Shadervan' for business exchange and coffee and tea talks during the whole year, whether outside or in the inner coffee and tea shops interiors. The fountain square - Shadervan preserved its importance because of its role as a crossroad of main bazaar streets.

\footnotetext{
${ }^{11}$ Jacobs, J. (1962) The Death and Life of Great American Cities, Edition 2000, Pimlico, Random House, London

${ }^{12}$ Gehl, J. Svarre, (B. 2013) How to Study Public Life - Island Press, Washington, DC, USA
} 
This remained even during the communism time when the esnafs dissolved and the shops were partly nationalized, and artisan's products declined due to more industrialized production. Shadervan or Fountain Square is the central square in the city of Prizren dating back from the $15 / 16$ century. It is a typical square positioned in the intersection of main pedestrian axis in the city, leading to Sinan Pasha Mosque in the city centre. It is enclosed by the cafes and shops with maximum three stories that provide a human scale of the square. Most of the architectural features of the buildings are from the end of 19th and beginning of 20th century, the period when old shops were refurbished. Light colours with little details make the urban architecture fit the purpose of the square.

The urban landscape is dominated by the 17th century Sinan Pasha Mosque, a traditional Ottoman mosque with dome and minaret. The Mosque possesses some monumental features such as big portique elevated more than 3,00 meters from the street level due to the topography. The floor of the square and the streets that terminates in the square is paved with granite cobblestone. Originally the floor was stone paved taken from the river. Recently the drinking fountain made of stone was refurbished.

The square is characterized by a set of formal and informal activities that takes place during the day. A very lively public life through the whole day can be experienced in the square. There are periods during the year when the square is full of people through the night until early hours in the morning. This usually takes place during the DOKUFEST - the International Festival of Documentary Film in the summer, when the square becomes a kind of living room for all citizens and visitors of the festival. In the morning you can drink coffee or tea and have light breakfast in the terraces or inside. Then, around noon people gradually fill up the area around, sit in the cafes or do shopping. The street vendors are usually in the west side. They sell festival tickets and souvenirs.

Beside the environmental and social values possessed, the square is a very vital economic spot in the city. Cafes and shops are viable businesses that contribute to the vitality of the square. At the same time, they play an important role for the safety of the place. In the other side, the use of the terraces provides some incomes for the municipality from tax incentives necessary for an effective maintenance. A mix of stakeholders in the square takes care on how the square is maintained. Shop-keepers, and local civil society organisations constantly keeps warning the city department for public services on whatever the square may need in terms of maintenance. 

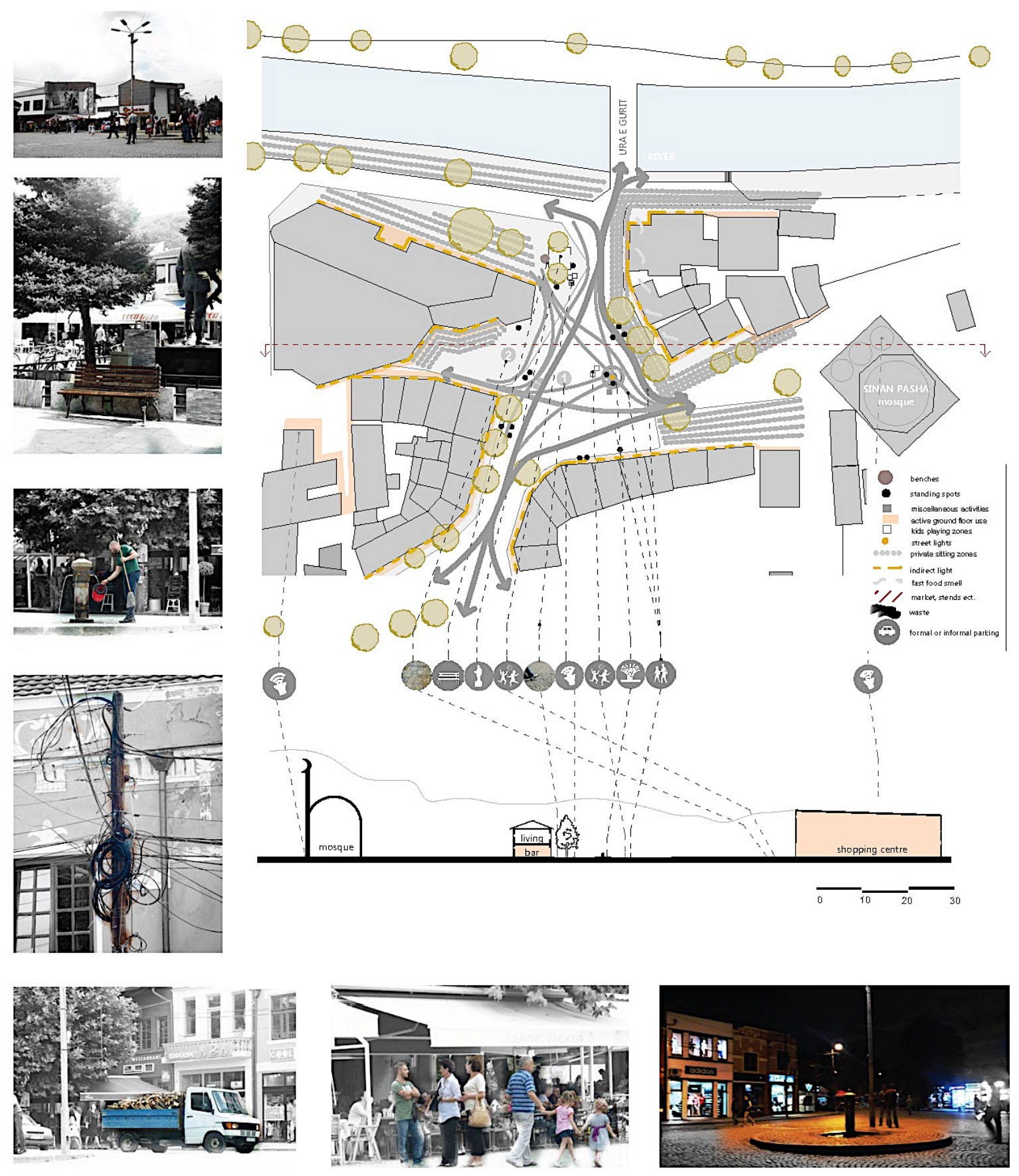

Fig.1 SHADERVAN - (The Fountain Square) - Prizren

\section{ÇARSHIA E MADHE (Grand Bazaar) and LAMA E DRITHIT (Grain Market) Gjakova}

The Grand Bazaar is the central part of the Ottoman core of Gjakova. It dates back to $16^{\text {th }}$ $17^{\text {th }}$ century. It has more than 500 shops and is known as one of the largest bazaar in the Eastern Europe. It has housed a wide number of artisan and trade shops of different production such as processing of metals, leather, textile, wood, and necessary services for the citizens. Until 1873 it was a very important economic centre due to strong commercial connections with Shkodra and the Adriatic coast, through which the export of production was enabled in the region of the 
trading route (Shkodra-Gjakova-Nish-Sofia-Istanbul). With the construction of the Thessaloniki - Skopje- Mitrovica railway (1873), the bazaar declined due to shifting of the trade routes in the Balkans. The Bazaar was the centre of the development of social and political life of the city. The esnafs/guilds played an important role in the social and economic life not only in the bazaar, but in the city and the wider region as well. The esnafs, contributed to preserve the crafts and transferred their tradition from generation to generation. ${ }^{13}$ During the Balkan wars in 1912 it was destroyedand due to the new borders in the interwar period it declined as a continuous decline of artisan production and competition with imported industrial products. After World War II, due to the rapid industrialisation, the Grand Bazaar lost the role it once had in the Ottoman Empire. The Grand Bazaar area is under protection by the decision No. 59/ 55 from 02.19.1955. According to documents the main crafts exercised in the bazaar were: wool-makers, curriers, shoemakers, tailors, tanners, cutlers, sword makers, blacksmiths, tinsmiths, saddlers, gunsmiths, watchmakers, goldsmiths and silversmiths/filigrees etc. Currently most of the buildings are residential spread across the whole area of the bazaar. Shops and other commercial buildings extend along the bazaar streets Most of the uses differ from the initial use due to decline of the artisan production. ${ }^{14}$ Currently the Municipality is undergoing a project for urban revitalization. Recently it turned to pedestrian area to claim back the human scale of a typical Ottoman bazaar. It is gradually shifting from artisan production features to commercial area with shops and restaurants, which has brought certain vitality in the city. The physical structure and the architecture have been preserved to a certain extent, because it was already revitalized in the 1980's. The public life is mostly based on the shopping, food and drinking opportunities and leisure. Some traditional event is being organized in the bazaar.

\section{LAMA E DRITHIT - Grain Market - Gjakova}

Lama e Drithit is a small square within the Grand Bazaar. It is a place originally dedicated to the farmers who brought to the city market their grain products. Although the grains are not products that are being trade in the city, the name tells us also what the square was used for and where would the farmers be able to expose their products. Encountered with one-store shops in a triangle shape, the square is place where several Bazaar streets terminate. The simple Ottoman architecture with pitched roof covered with antique roof tiles, usually handmade, with big wood windows and shutters that stands open during the whole day and closes when the shops are closed. As the windows were usually standing open, the square extended inside the private space so the vendors followed everything happening in the square. In the other side, those outside could

\footnotetext{
${ }^{13}$ Historic Urban Area - Framework for the regeneration of the Grand Gjakova Bazaar - CHwB, Prishitnna/Gjakova (2015)

${ }^{14}$ Ibid 6.
} 
communicate with the vendors or may enter the shop. The common activities we can find in the square, mostly trade and services. The square is characterized by a set of formal and informal activities that takes place during the day. A very lively public life through the whole day can be experienced in the square, livelier in the summer when people spend more time in the open spaces. In the morning coffee or tea bring together vendors where they discuss general issues, business, politics and other gossips that tare spread in the city and bazaar. Then, around noon people gradually fill up the area around, sit in the cafes or do shopping. There are no street vendors as it was before in the Ottoman period. Rather, the place now is dedicated for are usually in the west side. Cafes and shops contribute to the vitality of the square and at the same time they provide safety of the place. Use of the outdoors terraces of the cafes provide some incomes for the tax incentives to municipality necessary for maintenance. A mix of stakeholders in the square takes care on how the square is maintained.
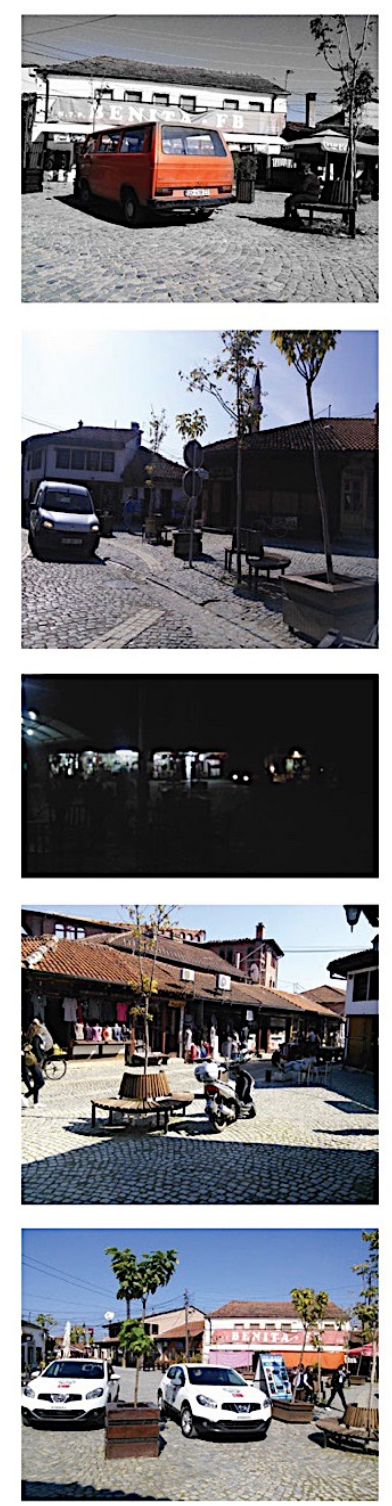

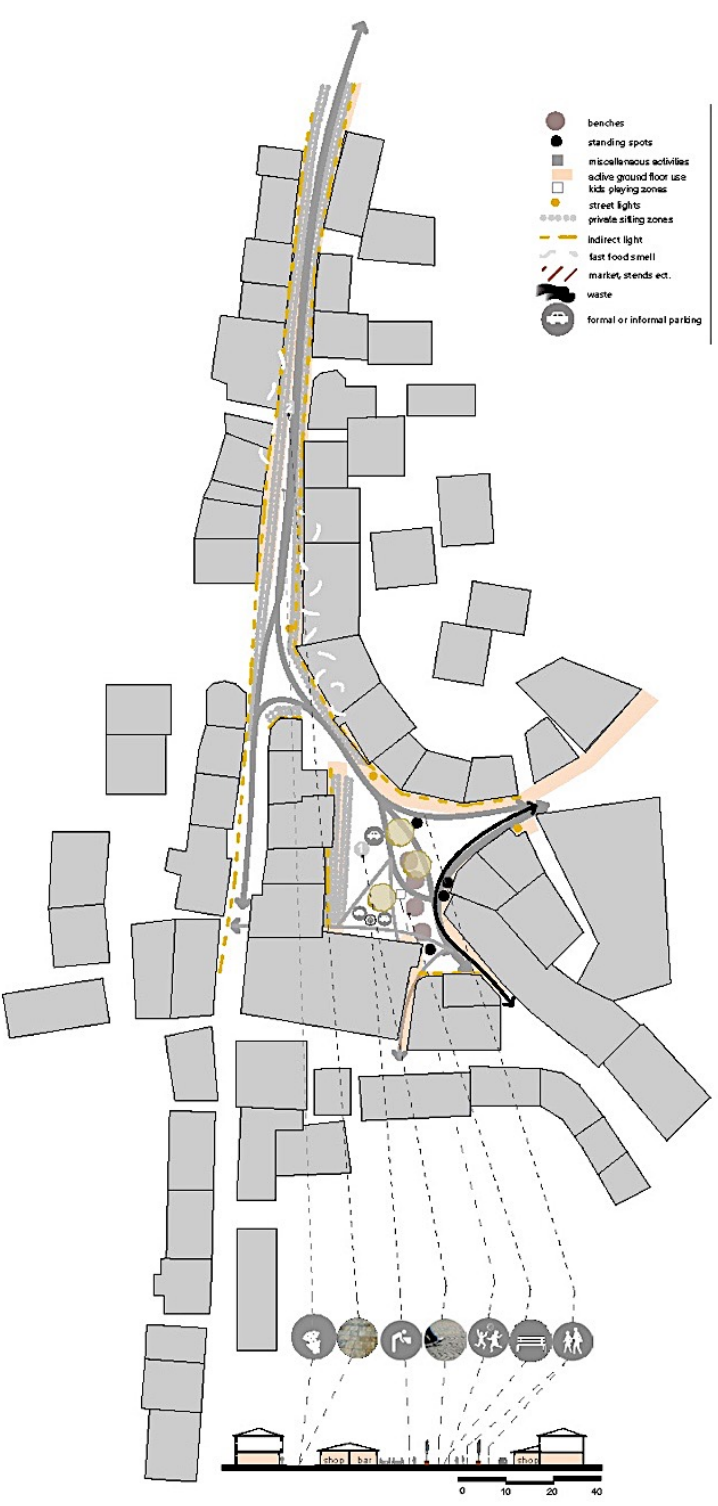

Fig.2 ÇARSHIA E MADHE (Grand Bazaar), LAMA E DRITHIT (Grain Market) - Gjakova 


\section{ÇARSHIA E GATË (The Bazaar) and LAMA (The Market) - Peja}

The bazaar case shown in this study includes the bazaar- çarshia and the square - Lama as a place where several streets terminate. It is the historical area - part of Peja Kulliye including Bayrakli Mosque, Hanan and the han. The intensive use of bazaar nowadays could be considered as an incontestable argument that since the medieval period, it used to be the central area of the public life in the Ottoman town. Beside the artisan production and trade, the bazaar was the arena of social exchange - friends talks through food and drink on a daily basis or during the evenings in the holly month of Ramadan. The extension of the Mosque courtyard in the Lama square, makes it an arena of multiple public use, both in term of time dimension and variety of functions and user categories.

The bazaar consists on the street and the square. The 5-6 m' wide street is enclosed with small shops following the Ottoman principles od shaping the streets - architecture with pitched roof covered with antique roof tiles, with large wood windows and shutters opened during the whole day providing the extension of the street inside the private space so the vendors could follow everything happening in the street. In the other side, those outside could communicate with the vendors without entering the shop.

The Lama square is a small open place encompassed by the small shops, which give the liveliness to the square. It also provides some additional space when prying takes place outside the Bayrakli Mosque - during the Ramadan or Bayram Holidays.

The square is characterized by a set of formal and informal activities that takes place during the day. A very lively public life through the whole day can be experienced in the square, livelier in the summer when people spend more time in the open spaces. In the morning coffee or tea bring together vendors where they discuss general issues, business, politics and other gossips that tare spread in the city and bazaar. Then, around noon people gradually fill up the area around, sit in the cafes or do shopping.

There are no street vendors as it was before in the Ottoman period. Rather, the place now is dedicated for are usually in the west side. The common activities we can find in the bazaar and the square, mostly trade and services. From the activities in the past the only ones to survive are some blacksmiths and traditional costume producers. The traditional costumes are used only during different event ceremonies, such as weddings.

Peja was famous for its textile manufacturing, and the çarshia was a perfect place for selling of local textile products. In turn, these products made the çarshia famous in the wider region. Çarshia is the place to also buy cheap products usually imported from Turkey. Cafes and shops 
contribute to the vitality of the bazaar and the square and at the same time they provide safety of the place. Use of the outdoors terraces of the cafes provides some incomes for the tax incentives to municipality necessary for maintenance. A mix of stakeholders in the bazaar including the community of Bayrakli Mosque takes care for the maintenance albeit it is the responsibility of the municipal Public Service Department.

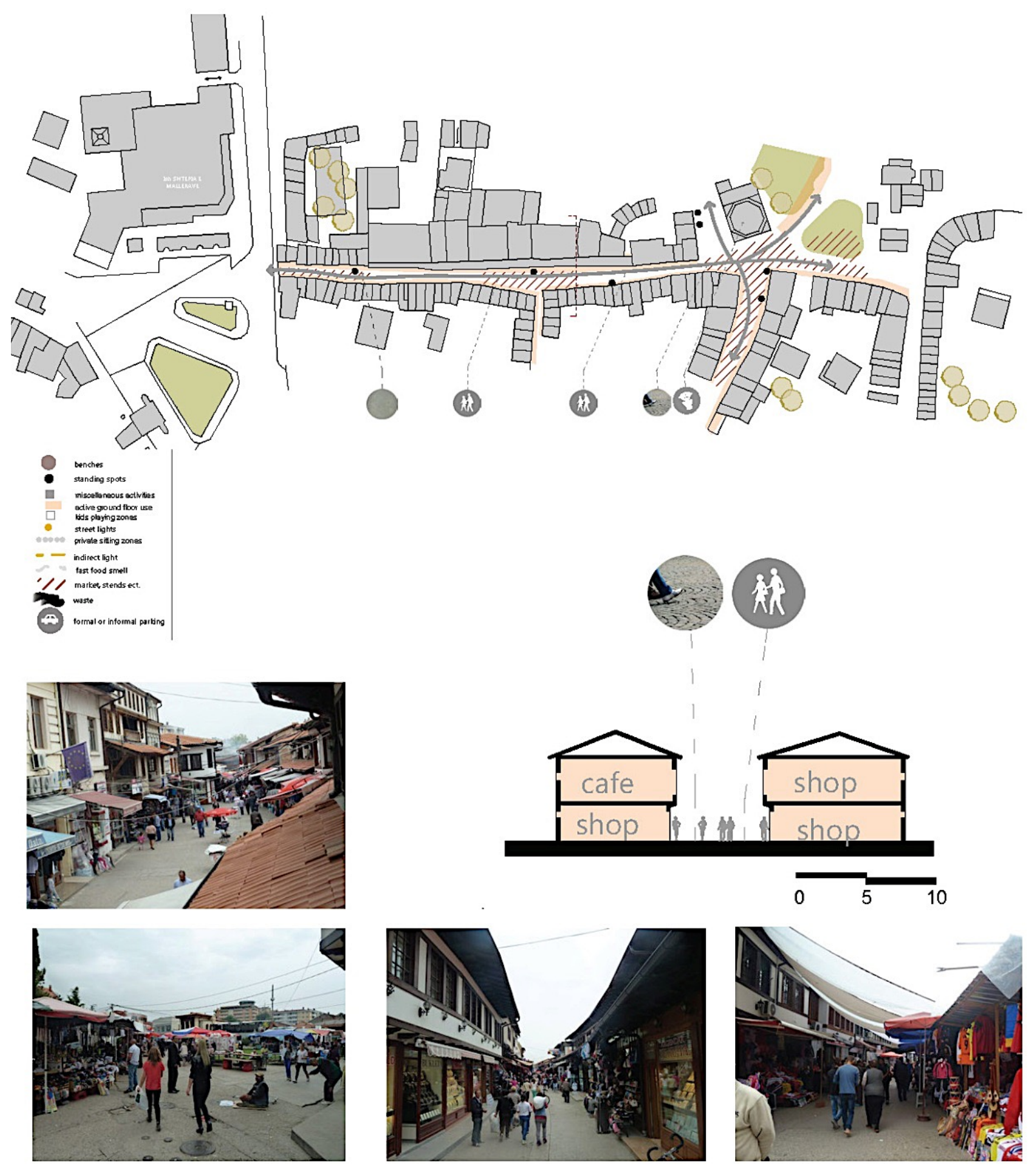

Fig. 3 ÇARSHIA E GATË (The Bazaar), LAMA (The Market) - Peja 


\section{OTTOMAN GARDENS}

\section{‘TAUKBAHCE’ PARK - Prishtina}

Taukbahçe is a park, formerly northeast periphery of Prishtina. It lies in the valley of Vellusha stream between two hills and is characterized with dense planting of high trees. It dates back to $19^{\text {th }}$ century, referring to its Turkish name meaning: chicken garden. Taukbahçe has been a suburban garden where Prishtina residents used to go for walking and enjoying nature. As city grew, it became closer to the city so it may be considered as a city park.

From the early hours in the morning people gets to the Tukbahçe for morning jogging, walking or have morning coffee in one of the two cafes within the park. The park is dominated by the high trees, and has two longitudinal paths, one along the stream Vellusha. In the northern side the park is encountered with the Tashlixhe neighbourhood settled in a steep hill. In the southern part is a dense green forest in a steep hill, which contributes to the overall natural settings of the park. Different trees can be distinguished in the park such as linden, acacia, wild chestnut, elm, maple.

In the recent years there has been some refurbishment works in the park. The paths have been paved, stream regulated with stone-concrete bed and some public lighting added. The poor design and works done suggests that there are no professional landscape designers involved in this project. At the western entrance to the park there is a private children playground rented by the municipality. This small amusement park attracts mostly children and young couples with small children and is very lively during the summer and in the afternoons after working hours. Most of the activities in the park are walking, sitting, playing and eating and drinking.

The most frequented part of the day in the park is the in the noon and in the evening, although this depend on the weather and the day in the week. Within the park area there is a tennis sport field and a football pitch, managed by the private entities. In the other side of the park, there is café and restaurant with a terrace, managed also by a private owner.

The care for the trees and shrubs is not periodically conducted, so some older trees are damaged and may fall down. Private entities using the park are also stakeholders in the park management concerning the space that they are using. Renting parts of the park provides the opportunities for more activities in the park and also incentives for maintenance of the park. 

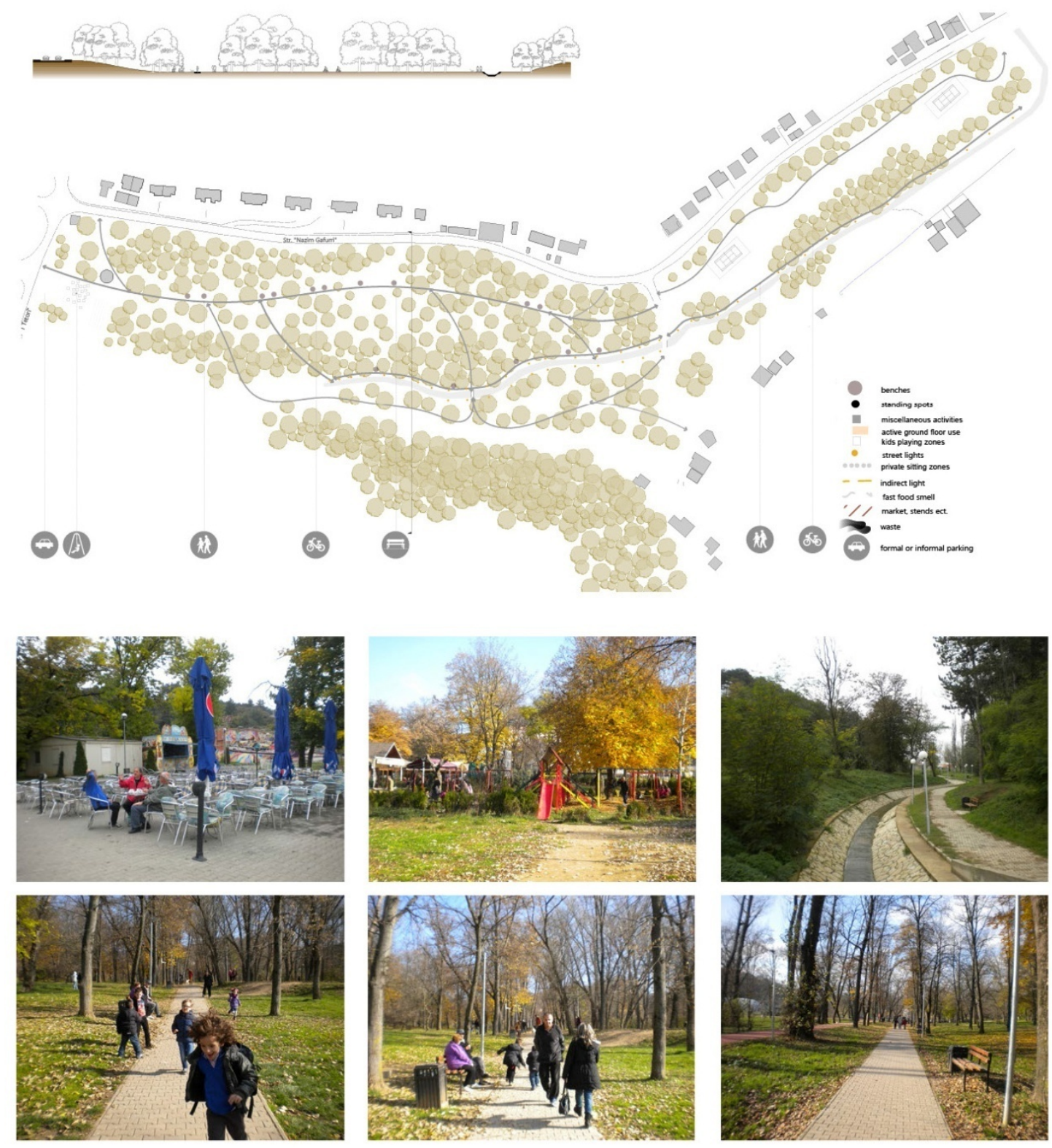

Fig. 4 'TAUKBAHCE' PARK - Prishtina

\section{'MARASHI' PARK - Prizren}

Marash complex located in the eastern outskirts of Prizren, where Shar mountains terminates in the Lumbardhi river. It is a green area from ottoman period - a 'mesire' which had preserved its importance and vitality it had since than. Marash Park is a green belt, which links the fortress with the city and PrizrenLigue Centre along the Lumbardhi river with a walking promenade with poplar tree alley. A 400-year old plane tree - (Platanus- Orientalis), two meters wide, is the only example of its kind in the Balkans is one of the special attractions of Marash. Located near the center of town, but at the same time hidden from the crowd, this park offers a warm environment with jogging trails, which runs for kilometers up to the first power plant of Prizren from the beginning of $20^{\text {th }}$ century. There are paths leading to the fortress, sitting and play areas and some small cafe-restaurants. From Marash Park the paths lead to Dokufest Camp with the opportunity 
for walking upstream of the river, with the trails running several kilometers for walking and biking along the Lumbardhi riverfront, a magnificent natural setting. Upon entering in the Marash one can feel the fresh breezing of the cold Lumbardhi water that runs from the Sharr mountains gripped with the freshness of mild mountain climate is combined with Mediterranean climate. Marash is considered a pleasant symbiosis of natural and architectural heritage. At the park entrance some of the Prizren architectural heritage sites could be experienced such as Maksut Pasha Mosque 1833 the Türbe/Tomb of Saadi order and the revitalized Pintolli mill which provide a local food specialty. In the upper end, the Prisren's first Power Plant is recently revitalized. Marash is a very visited and lively area especially in the spring and summer. People walk and run from the early morning hours but there are also food and drink opportunities and the open-air music in the summer, which make the park a convivial area. During the DOKUFEST film festival the Camp organizes the music night events, which runs through the whole night, for 10 days
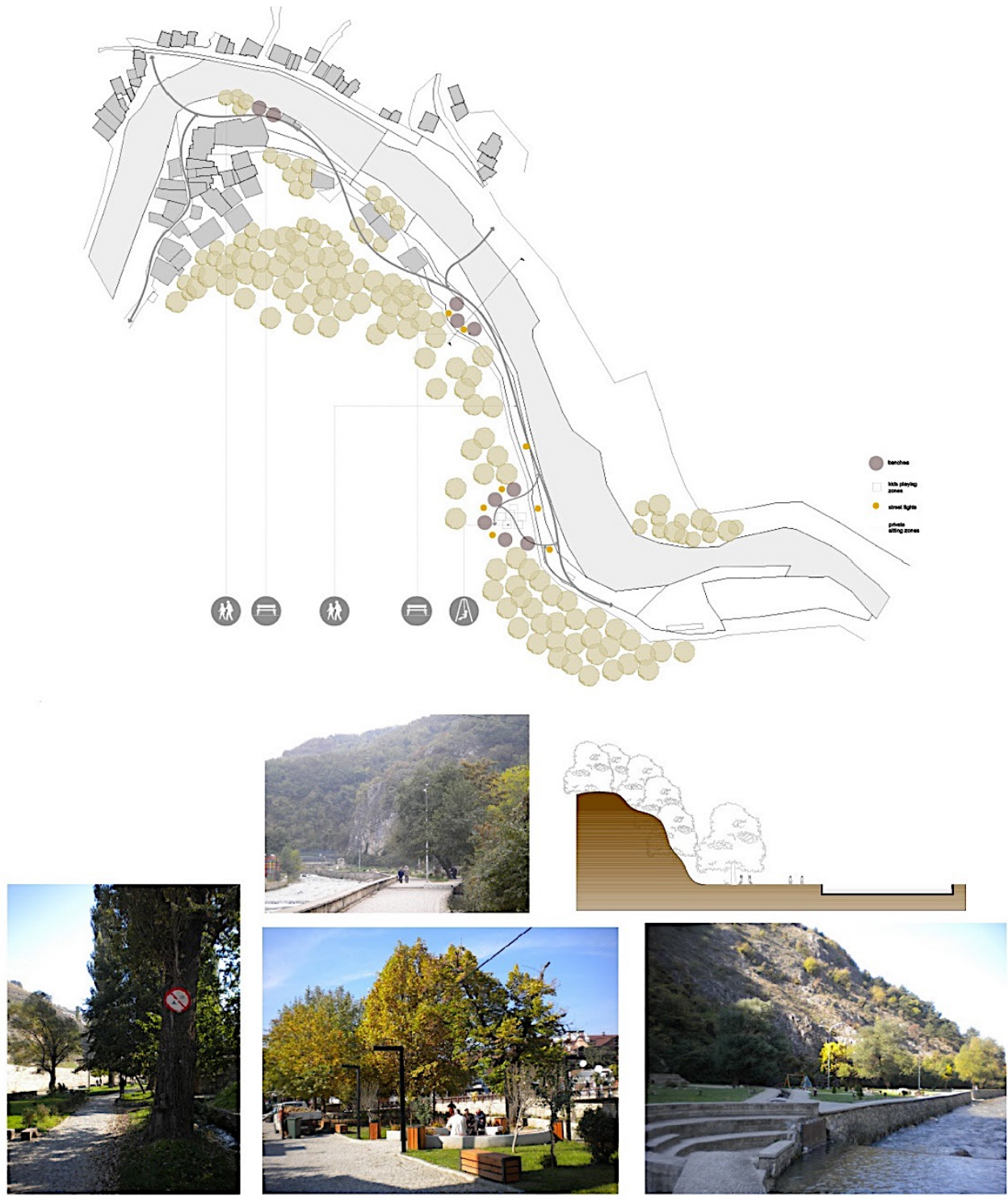

Fig. 5 'MARASHI' Park - Prizren 


\section{‘KARAAGAÇ’ Park - Peja}

Karaagaç park dates back in the Ottoman period. In Turkish karaagaç means elm tree the most popular tree used in the Ottoman gardens, due to its big and dense crown. In the Ottoman period, Karaagaç was a leisure park in the periphery of Peja, in the footstep of Kosovo Alps. In the period between two wars, Serbian authorities added a network of pedestrian paths and a fountain. During the modern period, it was a very popular park where citizens used to go for leisure. After the World War II a swimming pool was built in the southern part of the park, which in the 80's and 90 's, due to maintenance costs was inactive for a long time. Karaagaç is a big park with high and mature trees. A wide-open area along the fountain offers place to sit in $t$ he sunshine while big trees that are spread all over the park provide sanctuary from the hot summer days and place to relax. The park is only a 5-minute walk from the city centre. Due to this position in the city, the park is intensively used, although it lacks sufficient urban furniture such as sitting, proper lighting, bins etc. In the morning, older people come to the park and you could find people jogging and walking as well. There are a variety of users during the day. After the war, the pool was refurbished offering an opportunity for swimming and recreation in the hot summer days. Recently, municipal authorities have given more attention to the maintenance of the park so the care about the cleaning and vegetation is more visible. Karaagaç is under transformation into the university campus and sport and recreation area. With this transformation, the park will be enlarged and become part of a big sport and recreational area in the city from which there will be a direct link to the ski slopes in the mountain area.
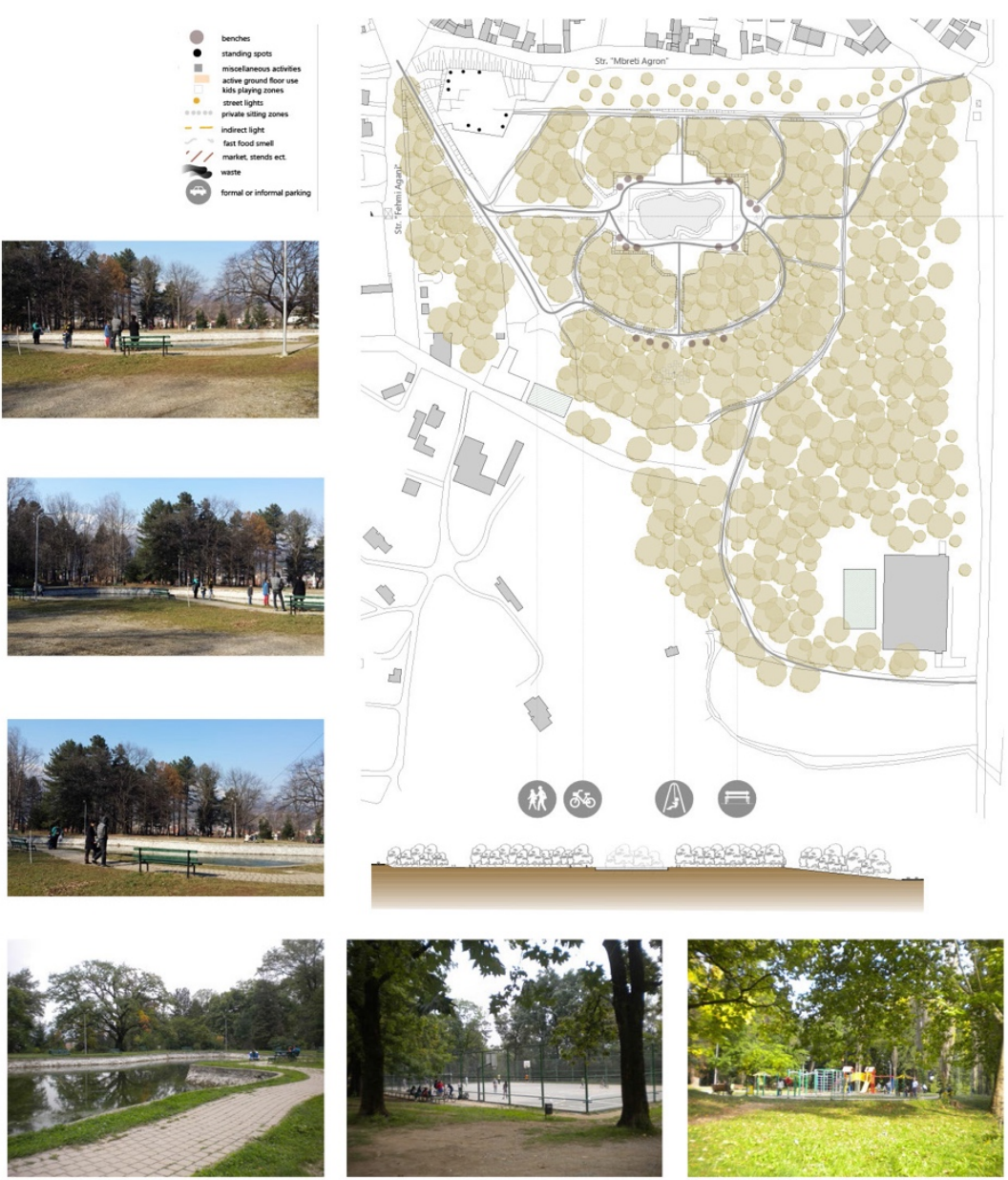

Peja 


\section{II - COMPARATIVE ANALYSES}

The correlational research strategy intends to clarify patterns of relationships between two or more variables, that is, factors involved in the circumstances under study. ${ }^{15}$ The following general characteristics of correlational research can be identified:

- Focus on naturally occurring patterns;

- Measurement of specific variables;

- Use of statistics to clarify patterns of relationships.

Focusing on naturally occurring patterns, a researcher tries to understand the behavioural dynamics of public space use, and in particular what physical features would encourage their use. Correlational research strategy seeks to clarify the relationship among a complex set of realworld variables. ${ }^{16}$ Variables mean a range of features such as: physical features, social/people, functional/activities, or of meanings/place, that vary within the circumstance being studied and are also likely to affect the dynamics of socio-physical interaction. Correlational design assumes that the researcher simply measures the variables of interest and analyses the relations among them. ${ }^{17}$

\section{RESULTS}

Selected public spaces in this research are most visited places in the respective cities. The comparison intends to show if the average use of public space relates to particular values that each of them carries such as history and meanings, visual appropriateness, protection, possibilities and comfort. The average people's presence in the public spaces in different hours during the weekdays and in the weekend for different typologies was used to define the features that all of these. As expected, public spaces in the historic core of the city and car free public spaces were more visited than the areas where car traffic is integrated with the pedestrians. Small squares in the city centres are usually more visited due to the variety of the uses that are present and cultural heritage and meanings that they carry. The number of people, safety, comfort, and visual appropriateness are compared and presented in the following pages. The number of people related to three main features in the public space can suggest the necessary measures to be taken for improvements. The comparisons were made based on the typology Square, Street, City park. They possess historical features with meanings embedded in them, showing in particular transformations through history of functional, social and visual dimension.

\footnotetext{
${ }^{15}$ Groat, L.N., Wang D. (2013) Architectural Research Methods - Second Edition, John Wiley \& Sons, Inc., Hoboken, New Jersey

${ }^{16} \mathrm{Ibid}, 1$

${ }^{17}$ Ibid, 1
} 


\subsection{OTTOMAN SQUARES}

The first group of Public spaces are squares in the city centres. The Shadervan Square in Prizren, The Lama e Drithit/Grain Market in Gjakova, and The Lama/Market in Peja are the main squares in the respective cities. The Squares in Prizren, Gjakova and Peja are considered Ottoman squares because they are in the city core and also part of the ottoman bazaars.

\section{Number of People}

In terms of use, the number of peoples present in these places differs a lot. There are several reasons starting from the size of the city, role that it may have in the region, position in the city, presence of architectural heritage, presence of natural elements, water, eating and drinking opportunities and tourism as a feature that is becoming more important. Shadervan could be considered one of the most valued Ottoman squares because of its position in the city and Prizren is a cultural heritage site.

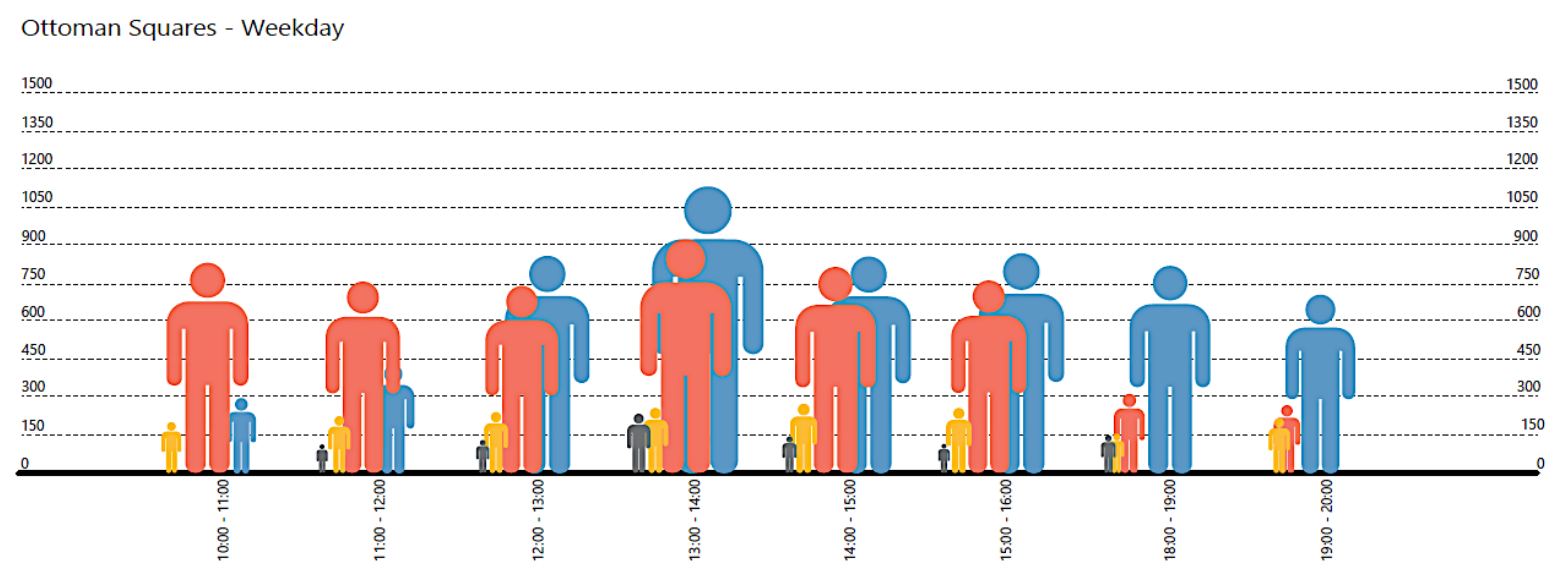

Ottoman Squares - Weekend

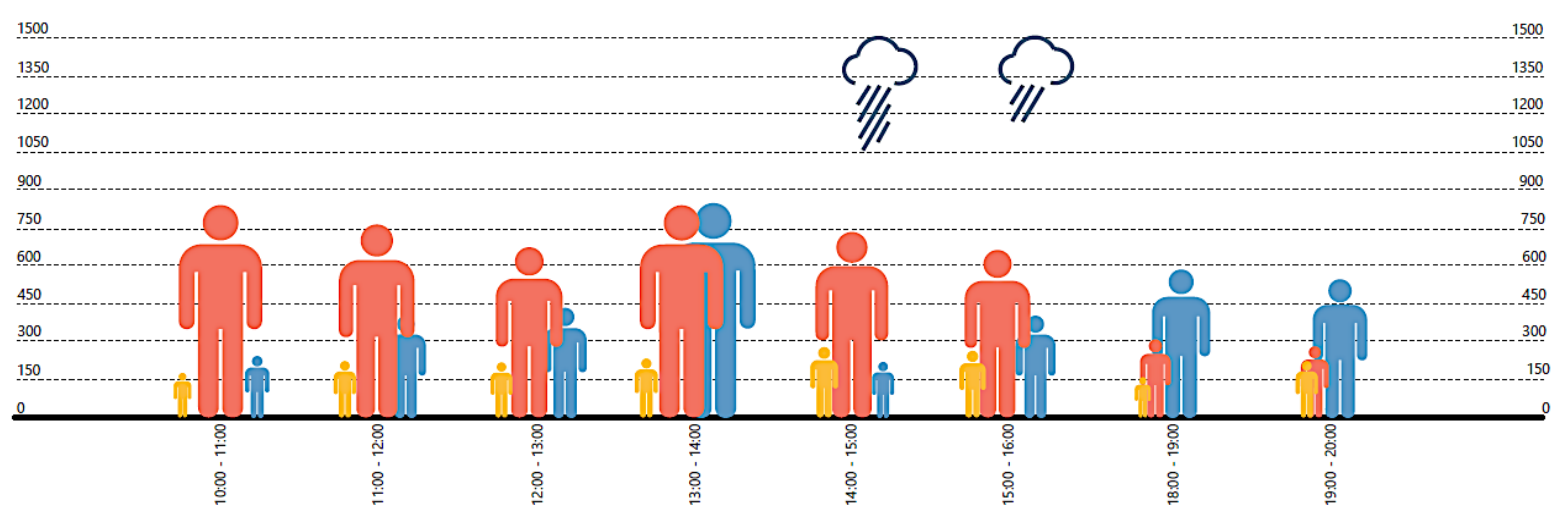

Ottoman Squares

Site

Shadervan Square

Lama e Drithit

Market
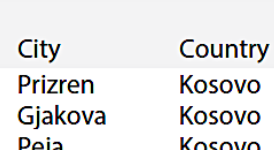

\begin{tabular}{cc}
\multicolumn{2}{c}{ Weekday } \\
High & Low \\
1300 & 35 \\
240 & 160 \\
900 & 280
\end{tabular}

\begin{tabular}{cr}
\multicolumn{2}{c}{ Weekend } \\
High & Low \\
820 & 200 \\
225 & 160 \\
800 & 280
\end{tabular}

Fig. 7 Analyses of people in the public space - Ottoman sqaures 


\section{Safety}

In terms of protection, the results were summarised in the following conclusion surveys show that all three squares are characterised by similar results, which proves that these places are safe from car accidents. Limited access for cars, few cyclists and unorganized walking lines contributes to pedestrian safety. There are no obstacles and physical barriers for free movement. A vey lively place through the whole day until late evening hours. Public lighting, although inappropriate for the character of the square, provide sufficient security in the evening. Conviviality of Shadervan squares and public lighting contributes to a safe environment and violence prevention. Lama e Drithit in Gjakova has similar characteristics but the average of number of people is less than in Prizren. In Lama/Market in Peja, the average number of people is much higher during the day but due to uses of the shops, it declines in the evening. We could conclude that there several features that determines the safety in the public spaces amongst them number of people, variety of uses, absence of car traffic and good public lighting.

\section{Comfort}

In terms of comfort, these squares have similar features with some variations, which include different floor, different uses and presence of natural elements - trees, water and proximity of the river such as in Prizren. The central position in the city, bazaar, summer-time, architectural heritage, shops, are features that contributes to comfort and are present in all squares.

Activities such walking, standing, sitting and talking takes place, in all squares are intensively present during the day but in the evening differs. While in Prizren until late evening hours Shadervan Square is full of people, in Gjakova number of people in the evening is slightly lower. In Peja Market it diminishes drastically compare to presence during the day.

Protection from unpleasant climate is a factor that provides a certain degree of comfort in terms of standing, sitting and talking in the public spaces. Standing and sitting is possible mainly close to the shops and talking is fostered by availability of sitting. No covered areas for shelter from sun, rain and snow, to protect from climate except the porches of the cafes.

Small area for walking, short distances, part of the Bazaar complex and stone non-slippery floor with little damages presents the common image of the squares. Some level variations may be obstacles for the handy-capped people. Eating and drinking is possible from early morning to the evening. All squares may house other activities - play, music or other performances, during different city events and festivals - such as DOKUFEST in Prizren a film festival which is now rated very high in the world. Gjakova and Peja tend also to use the place for events although not yet in a successful manner. 
What is common in negative sense for these squares is insufficient or missing urban furniture: sitting places/benches and chairs usually insufficient, while totally missing signs, phone boxes, post boxes, notice boards, city maps, waste separation bins. Public toilettes are also missing.

\section{Visual Appropriateness}

The general aesthetic experience is positive due to human scale of architectural heritage, although recent refurbishment of the square could not be considered a good example how to deal with a heritage site. A nice human scale view around is possible only in the terraces and coffee-shops. Common visual experience in these squares are architectural heritage features that carries meanings and memories of the city such as shops in the bazaar streets, Friday Mosque, but they differ due to background landscape. While in Prizren a strong mountain background juxtaposes the river and the valley, in Peja there is a set of fording mountains that creates a limitless in respective cities in the evening, lighting of the square and the buildings contributes to visual qualities in the evening. Albeit slight differences, general impression is that the squares are clean and well maintained with the contribution of the shopkeepers.

The score of the squares could be compared in the following table. In terms of features that support public life, it can be noted that the difference is not proportional with number of people.

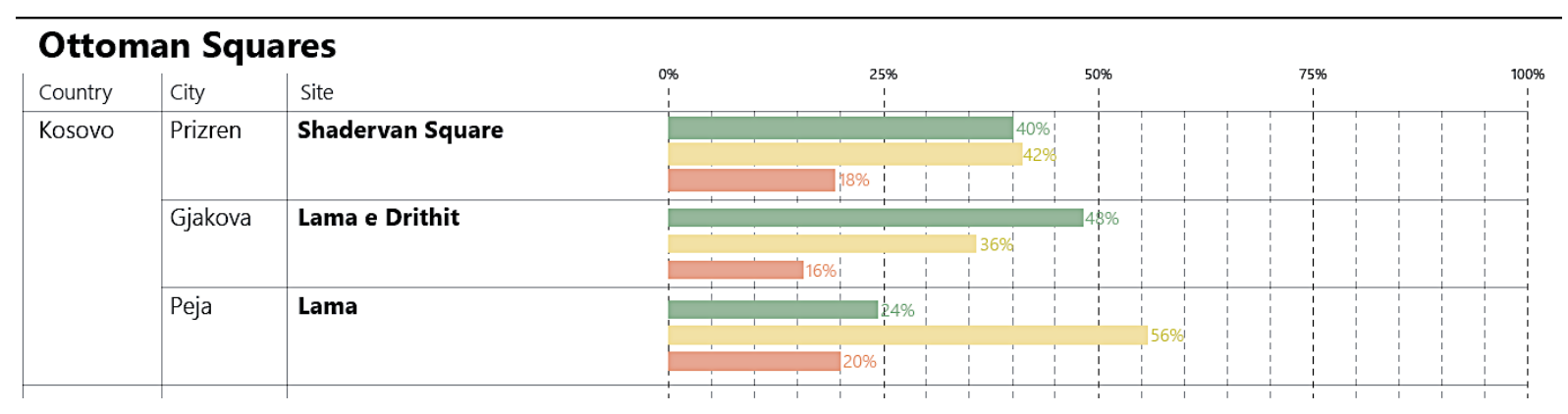

Fig. 8 Ottoman squares comparative analyses of spatial and public life qualities

\subsection{BAZAARS / ÇARSHIAS}

In this comparison we have chosen bazaars in, Peja, and Gjakova. Bazars in Peja and Gjakova which have preserved to a certain extent the urban morphology of the Ottoman bazaars, presents also the remaining core of the Ottoman city. Although burned down during the war in 1999, they were reconstructed and revitalised. These bazaars are still the liveliest parts of the city preserving the architectural and socio-economic features that they used to have. 


\section{Number of People}

Number of peoples present in the bazaars differs a lot from the shopping street. There main reason is the position in the city and the time dimension. Bazaars are heritage sites being lively for the ceturies. They have been tourism motifs for a long period and they are in the city centre.

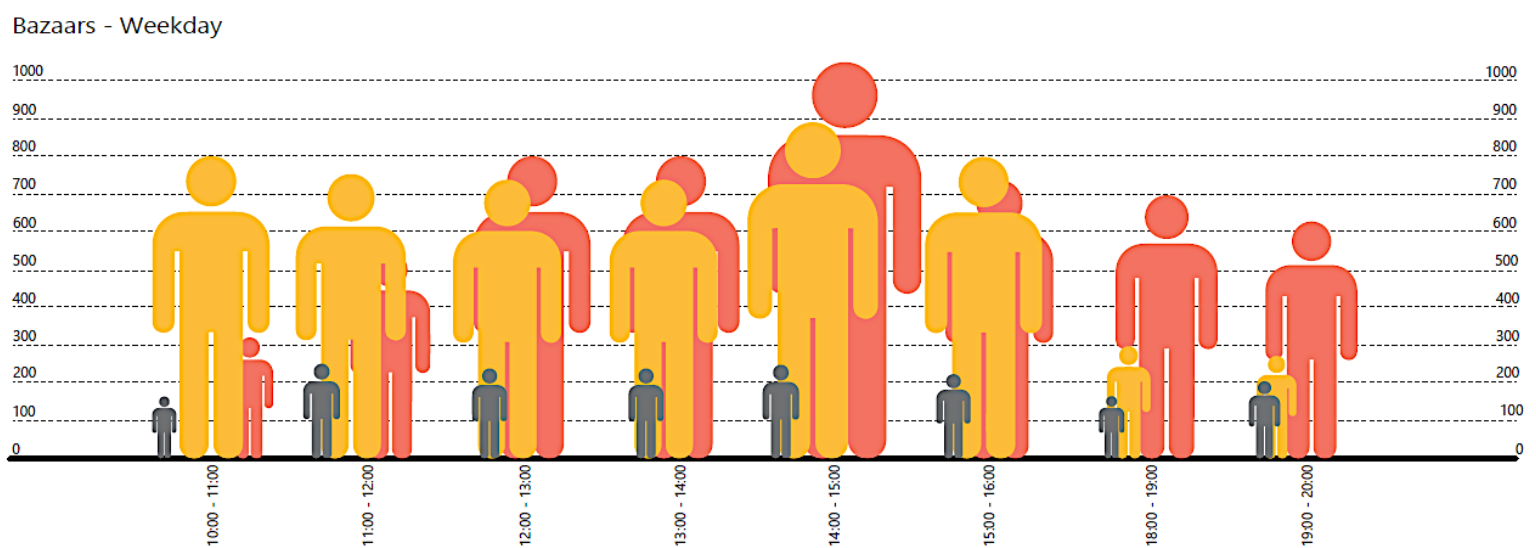

Bazaars - Weekend

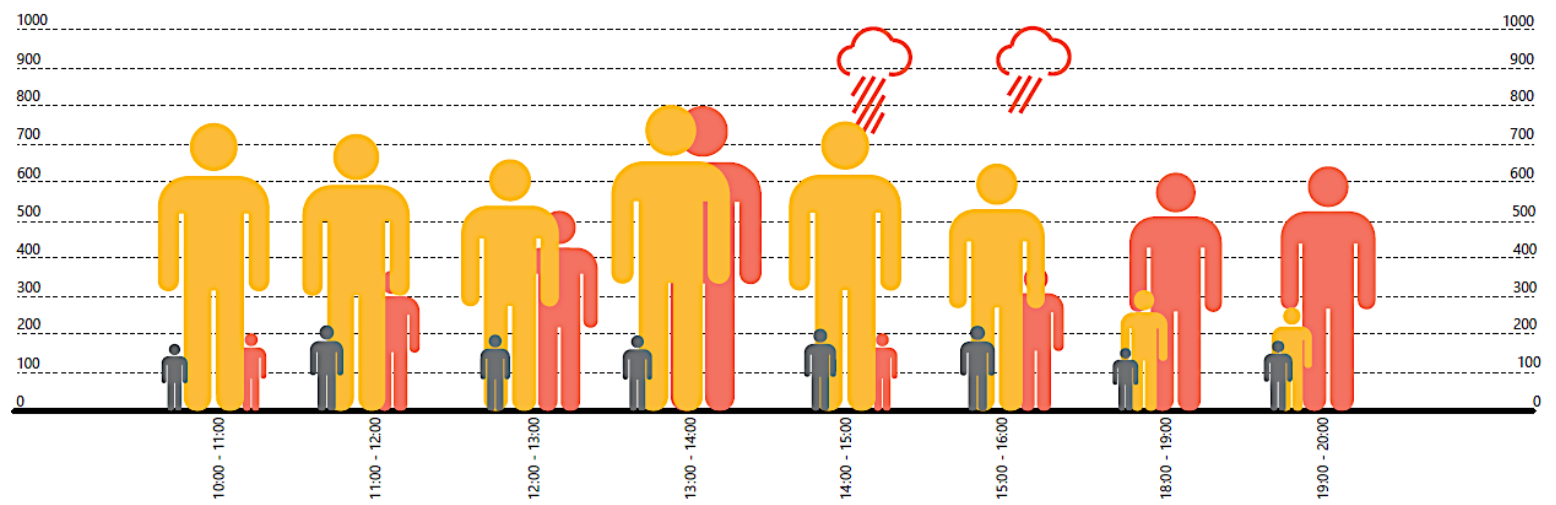

\begin{tabular}{lllrrrr}
\hline \multicolumn{1}{l|}{ Bazaars } & & \multicolumn{2}{c}{ Weekday } & \multicolumn{2}{c}{ Weekend } \\
Site & & & High & Low & High & Low \\
\hline Carshia e Madhe & Gjakova & Kosovo & 240 & 160 & 225 & 160 \\
Bazaar & Peja & Kosovo & 900 & 280 & 800 & 280 \\
Adem Jashari Street & Prizren & Kosovo & 1050 & 350 & 800
\end{tabular}

Fig. 9 Analyses of people in the public space - Ottoman bazaars

\section{Safety}

In this comparison we have two different cases- car-free streets in Gjakova and Peja and car and pedestrian street in Prizren as transformed bazaar street.car free street and square in Gjakova and Peja, open to cyclists contributes to pedestrian safety. Walking line along the shops and across the square towards the other street. There are no obstacles and physical barriers for free movement. 
Gjakova's bazaar is very lively place, used of mostly by adult people for walking, shopping, food and drinking, active throughout the whole day until late evening hours. In Peja and Prizren, due to mainly shopping uses in the evening the activities in the streets decline. Only walking is recorded. Passive engagement dominates the behaviour of people. Public lighting provides sufficient security in the evening. No crime has been recorded.

There is no shelter from sun rain and snow. The eves of the shops may be considered as shelter, but insufficient for all usersto protect fromunpleasant climate. The shops use parasols to provide the shadow. In Peja and Gjakova bazaars, loud music and uncontrolled smoke from fast food restaurants and bars present an unpleasant experience during the whole day.

\section{Comfort}

In terms of comfort, the bazaars in Gjakova and Peja, provides the plenty of possibilities in terms of walking, sitting, standing and talking. Walking street distances. Stone non-slippery floor with little damages. Some level variations may be obstacles for the handy-capped people.

Sitting with a nice human scale view around is possible only in the terraces and coffee-shops. There are few benches in the in the square under the trees. Talking mainly take place mainly at the cafes and fast-food restaurants and at the fountain, although sometime with unpleasant noise. Standing is possible mainly close to the shops.

Other activities may occur during city events such as festivals or celebrations. In Gjakova, in the end of summer the traditional food festival celebrated the summer harvests. The generators are central position in the city, bazaar, summer time, architectural heritage, shops. Street furniture is also missing; signs, phone boxes, post boxes, notice boards, and city maps. Public toilettes are also missing.

\section{Visual Appropriateness}

The general aesthetic experience is positive due to human scale of architectural heritage in Gjakova and Peja. In Gjakova, the views are mainly towards the bazaar street. In the evening, street and shop-front lighting contributes to visual qualities in the evening.

In Peja the Ottoman architectural heritage is combined with Kosovo Alps mountains view, which raises high in the city background. The Mosque views enriches the whole image of the Ottoman city core. In the evening, poor lighting of the square and the buildings do not provide conditions to use it in the evening. 
General impression is that these places are well maintained. In the bazaars and streets, the situation is even more neutral in terms of qualities off space related to number of people. Being in the bazaar/çarshia or shopping streets is a kind of tradition inherited from the Ottoman Empire. People go to these spaces to meet others, so as these spaces have a histories and memories, the other features become less important.

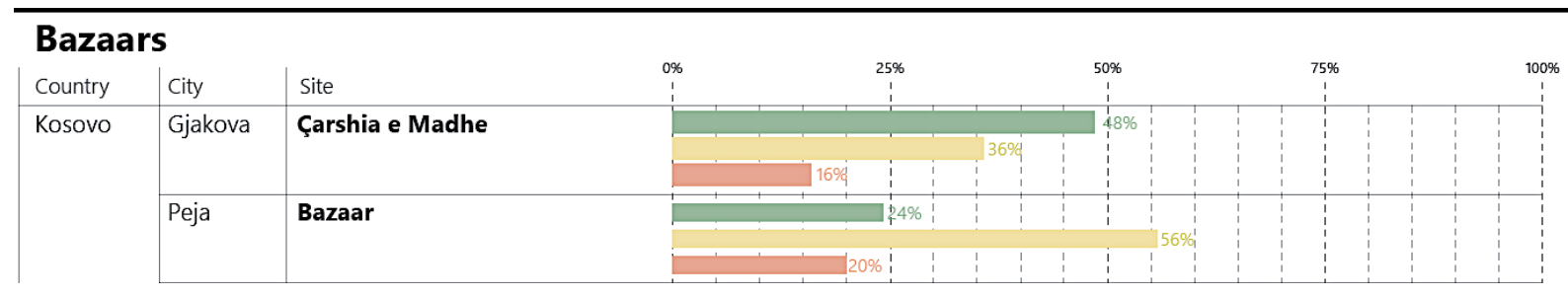

Fig. 10 Ottoman bazaars - comparative analyses of spatial and public life qualities

\subsection{OTTOMAN CITY PARKS}

These parks play still an important role for the public life in the Kosovo cities. Comparison of Taubahçe Park in Prishtina, Karaagaç Park in Peja and Marash Park in Prizren were chosen as samples of the oldest green areas in the cities. These parks could be regarded to the Ottoman period as mesire's - green areas in the city outskirts, where families used to go for leisure.

This fact is based on the tautonymy of the places: Tauk-bahçe = Chicken-garden in Turikish; Karaagaç $=$ Elm tree in Turkish which used to be the most tipcal tee usedin the Ottoman gardens; Marash $=$ Turish name for Germanicia Caesarea - an old Roman city in Asia Minor - now Kahramanmarash. These parks, due to the history and menaings, postion in the city and the natural features that they possess, trees and water features, could be attributed as natural cultural heritage as well.

\section{Number of People}

Ottoman city parks attract people probably because of tradition, mature high trees and position in the city away from car traffic. Number of peoples in the park differs due to positon and availability of other green spaces in the city. Presence of the water, in this case in Marash river Lumbardhi is probably the reason to have such a reputation. 


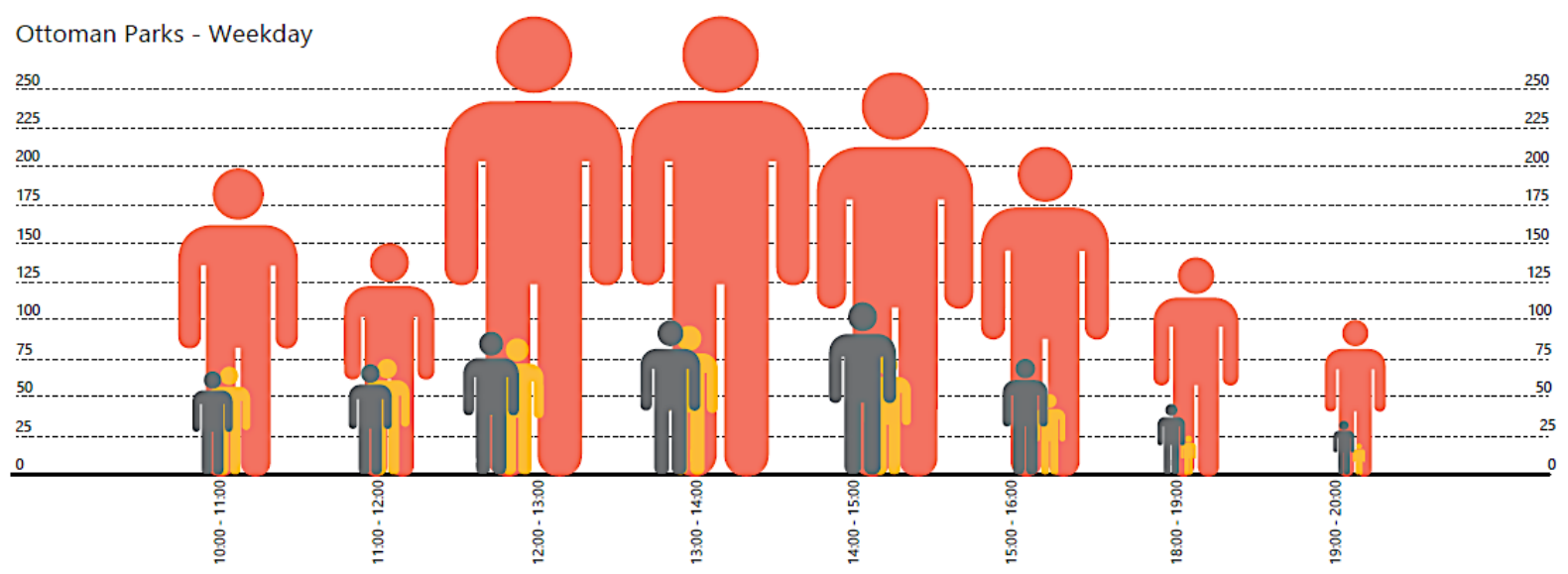

Ottoman Parks - Weekend

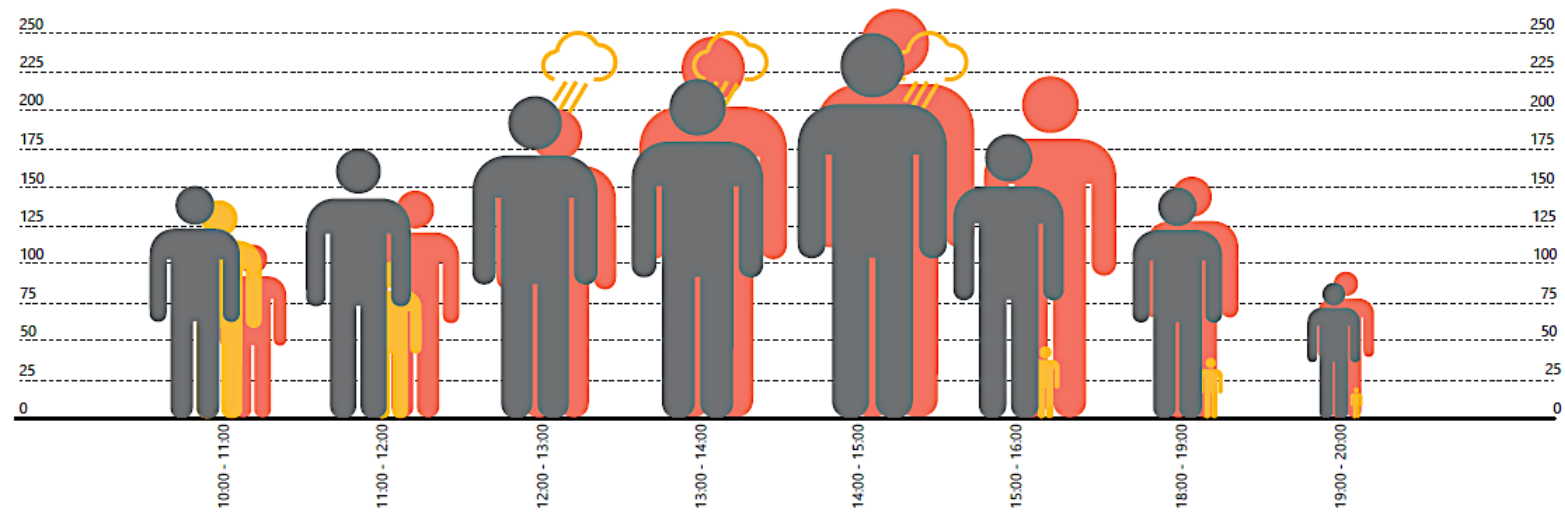

\begin{tabular}{|c|c|c|c|c|c|c|}
\hline \multirow{2}{*}{$\begin{array}{l}\text { Ottoman Parks } \\
\text { Site }\end{array}$} & & & \multicolumn{2}{|c|}{ Weekday } & \multicolumn{2}{|c|}{ Weekend } \\
\hline & & & High & Low & High & Low \\
\hline Taukbashçe & Prishtina & Kosovo & 110 & 30 & 250 & 80 \\
\hline Karagac & Peja & Kosovo & 90 & 20 & 140 & 20 \\
\hline Marash & Prizren & Kosovo & 400 & 100 & 340 & 80 \\
\hline
\end{tabular}

Fig. 11 Analyses of people in the public space - Ottoman city parks

\section{Safety}

The park is not prone to risks from traffic accidents. Walking and jogging paths, places for relaxing and playing are far from roads. The parks are fenced along the boundary streets. Walking and jogging paths, places for relaxing and playing are remote distance from roads. Lighting within the parks is insufficient. At Taukbahce Park, in the northern side of the park buildings in the residential area residential buildings, provide lighting during the night. The residential zones around the park, make it safer and livelier.

The Taukbahçe park and Marash Park, compared to park in Peja, are well used, but lack suitable components and activities for different age groups during the day. Due to the lack of safety at night, the parks are not attractive place for the citizens to visit. The lighting is not functional (lack of maintenance). 
Due to lack of maintenance in Karaagaç the public lighting is not working and the park is completely in the dark during night-time. Lack of residential zones around the park in Prizren and Peja, do not make them safe. The only safe places in the evening are around the restaurants located within the park. In Prizren, the surrounding spaces are not active enough and thus make the park inactive too. There is however a bit of activity near the restaurants just in the entry of the park.

In Prizren and Peja, there are cases of substance-abusing individuals, who are sometime present in the park, make it difficult for other people to visit.

\section{Comfort}

In terms of comfort all three parks could be rated as average quality parks. The main differences include topography, presence of natural elements - trees, water and proximity of the river such as in Prizren. At 'Taukbahçe' park, a small spring passes through the park, and, unfortunately, this is an unused potentialfor enriching the natural features of the park.

Activities such as walking, standing, sitting and talking takes place, in all parks, although a limited number of benches are available. Sometime, people use grassed areas to sit. While in Prshtina until late evening hours 'Taubahçe' offers sanctuary during the hot summer days is full of people, in Peja number of people in the evening is much lower. Marash Park is very lively during the festival events such as DOKUFEST - an international annual documentary film festival in Prizren. No covered areas for shelter from rain and snow, to protect from climate except the porches of the restaurants. Sufficient walking paths, walk able distances, also running paths in the greenery provide the opportunities for walking and running.

Eating and drinking is possible in the restaurants withinpark, but people also take their own food as well. In Marash park, along the north shore there are a set of restaurants and playgrounds, although not so attractive because of the river Lumbardhi which divide the park into two longitudinal strips. The Marash Park is used for other activities such as play, music or other performances, during DOKUFEST in Prizren. Peja Park is used also for the festivals such as ANIBAR International cartoon festival and BAR-Camp, a youth festival organized during the summer. What is common in negative sense for all parks is insufficient or missing urban furniture: sitting places/benches and chairs usually insufficient, while totally missing signs, phone boxes, post boxes, notice boards, city maps, waste separation bins. Public toilettes are also missing. 


\section{Visual Appropriateness}

The general aesthetic experience is positive due to high trees and dense greenery. This feature provides the shelter from the sunshine in the summer. Common visual experience in these squares are architectural natural features and memories that have been layered in the different stories about the cityNatural views dominates in all three parks. As Taukbahce lies in Germiavalley, the views are closed by the high trees. At Marash, the greenery is dominated by the Rocky Mountains that goes more than 1000 m' higher than the park floor. From Karaagac park in Peja, the Kosovo Alps and Peja valley provide a wide landscape scenery, unique for the whole Kosovo and the region. Albeit slight differences, general impression is that the parks are not well maintained. Especially the trees are not maintained - seasonal treatment is not carried according to needs.

\section{Ottoman Parks}

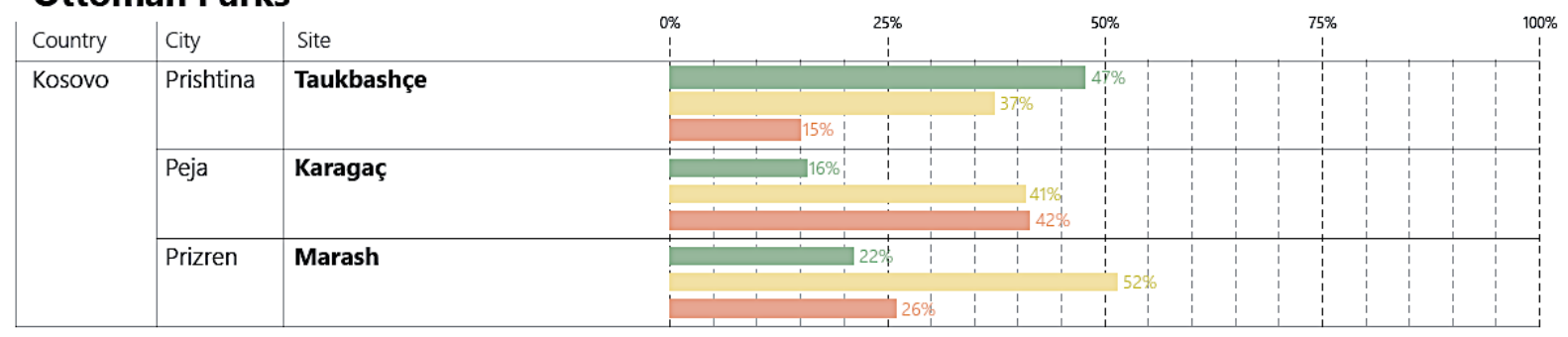

Fig. 12 Ottoman parks - comparative analyses of spatial and public life qualities

\section{CONCLUSIONS}

\section{GENERAL}

- Selected public spaces in this research are most visited places in the respective cities. The comparison intends to show if the average use of public space relates to particular values that each of them carries such as history and meanings, visual appropriateness, protection, possibilities and comfort.

- As expected, public spaces in the historic core of the city and car free public spaces were more visited than the areas where car traffic is integrated with the pedestrian movement. Small squares in the city centres are usually more visited due to the variety of the uses and cultural heritage and meanings that they carry.

- The number of people related to three main features in the public space, suggest necessary measures to be taken for improvements. 


\section{OTTOMAN SQUARES}

- In terms of protection, the results were summarised in the following conclusion surveys show that all three squares are characterised by similar results, which proves that these places are safe from car accidents.

- Limited access for cars, few cyclists and unorganized walking lines contributes to pedestrian safety. There are no obstacles and physical barriers for free movement. We can conclude that there are several features that determines the safety in the public spaces amongst them number of people, variety of uses, absence of car traffic and good public lighting.

- Activities such walking, standing, sitting and talking takes place, in all squares are intensively present during the day but in the evening differs. Small area for walking, short distances, being close to Bazaar complex and cobblestone, non-slippery floor with little damages presents the common image of the squares. Some level variations may be obstacles for the handicapped people. Eating and drinking is possible from early morning to the evening.

- What is common in negative sense for these squares is insufficient or missing urban furniture: sitting places/benches and chairs usually insufficient, while totally missing signs, phone boxes, post boxes, notice boards, city maps, waste separation bins. Public toilettes are also missing.

- The general aesthetic experience is positive due to human scale of architectural heritage, although recent refurbishment of the square could not be considered a good example how to deal with a heritage site. Albeit slight differences, general impression is that these squares are clean and well maintained with the contribution of the shopkeepers.

\section{BAZAARS}

- In the bazaars the main difference car traffic and pedestrian movement, so the main issue here becomes the safety of pedestrians. Car-free streets in Gjakova and Peja still keep the human sense of the space.

- Bazaars are lively place, used mostly by adult people for walking, shopping, food and drinking, active throughout the whole day until late evening hours. Passive engagement dominates the behaviour of people.

- In terms of comfort, the bazaars in Gjakova and Peja, provides the plenty of possibilities in terms of walking, sitting, standing and talking. Sitting with a nice human scale view around is possible only in the terraces and coffee shops but urban furniture is not sufficient. Talking 
mainly take place at the cafes and fast-food restaurants and at the fountain, although sometime with unpleasant noise.

- The general aesthetic experience is positive due to the human scale of architectural heritage.

\section{OTTOMAN PARKS}

- Ottoman Parks still keeps their fame in the respective cities. They are well used, safe from the traffic, but with a bit lower safety in the evening due to insufficient lighting. They are sometime used by the substance-abusing individuals, which make safety in the evening even lower.

- In terms of quality and comfort, we could conclude that the natural potential is not used to improve the comfort. In all parks the urban furniture is insufficient. Sometime they house different events that are periodically organised in the cities.

- The general aesthetic experience is positive due to high trees and dense greenery. Albeit slight differences, general impression is that the parks are not well maintained.

\section{RECOMMENDATIONS}

1. Policy-makers, designers and managers of public spaces need to provide physical improvements such as path connectivity, wide sidewalks, trees, and urban furniture;

2. Historic public spaces need particular care in terms of design and maintenance. As the pressure for transformation is constant, a wise policy should be established in order to balance the demands with the preservation provisions;

3. It is important to focus on the range of social and environmental qualities that support social life and the activities such as sitting and walking. Culture activities may increase the qualities of public life so the public spaces may become more convivial;

4. The key to achieve attractiveness could be enjoying scenery and social milieu and enjoying the health benefits of being in the public spaces especially those car free spaces. Improvement of public face of the buildings through façade colouring may also be a good tool;

5. The researchers should further consider environmental aspects emerging from increasing environmental problems both at the local and global level. For policy-makers, designers and managers of public spaces, the recommendation of this study is to consider simultaneously the physical, land-use and social aspects of the built environment to support walking. 


\section{REFERENCES}

Bentley, I., A. Alcock, P. Murrain, S. Mc Glynn and G. Smith (1985), Responsive Environments: A Manual for Designers, And Architectural Press London,

Carmona, M., Heath, T., Oc, T., Tiesdell S. (2003) Public Places-Urban Spaces, The Dimensions of Urban Design, Architectural Press, Oxford

Carr, S., Francis, M., Rivlin, L. G., \& Stone, A. M. (1992). Public space. Cambridge, UK: Cambridge University Press

Cipan, B. (1978) Makedonskitegradovivo XIX vekinivnataurbanaperspektiva, Academy of science and Arts of Macedonia, Skopje

Gehl, J. (2011) Life Between Buildings: Using Public Space, (6 ${ }^{\text {th }}$ ed.) Island Press, Washington DC

Gehl, J. (2010) Cities for People, Island Press, Washington DC

Gehl, J., Sware, B. (2013) How to Sudy Public Life, Earthscan, Washington DC

Groat, L.N., Wang D. (2013) Architectural Research Methods - (2 $2^{\text {nd }}$ ed.), John Wiley \& Sons, Inc., Hoboken, New Jersey

Hamadeh, Sh. (2008) The City's Pleasures-Istanbul in the Eighteenth Century, Splash and Spactacle, University of Washington Press, Seattle \& London

Hoexter M. (2002) The Waqf and the Public Sphere, in Public Sphere in Muslim Societies edited by Miriam Hoexter, Shmuel N. Eisenstadt, NehemiaLevitzon, State University of New York, Albany

Jacobs, J. (1961) The Death and Life of Great American Cities, Random House Inc, New York

Kojic, B. B. (1976), Staribalkanskigradovi, varosiivarosice, Institute for Architecture and Urbanism of Srbia, Belgrade

Kostof, S., (1995) A History of Architecture, Settings and Rituals, Oxford University Press, London

Lleshi, Q. (1977) Qytetet e Kosovës, Rilindja, Prishtina

Madanipur, A. (1996) Design of Urban Space - An Inquiry into a Socio-spatial Process, John Wiley \& Sons Ltd. Chichester, West Susex, England

Nikolic. S (1998), Prizren, from Medieval to Contemporary times, Prizren, Kosovo

Pinon, P. (2008), The Ottoman city of the Balkans, The City in the Islamic World (2 vols), Edited by Salma K. Jayyusi, Renata Holod, Attilio Petruccioli and André Raymond, Brill, Leiden

Relph, E. (1976) Place and Placelessness, Pion Limited, London, UK

Shkodra, Z. (1973) EsnafetShqiptare (Albanian Guilds), Institute of History, Academy of Science of Albania, Tirana

Tibbalds, F. (2001), Making People-Friendly Towns: Improving the Public Environment in Towns and Cities, ( $\left.2^{\text {nd }} e d n\right)$, London, Spon Press

Veinstein, G. (2008), The Ottoman town, 15-18th century, The City in the Islamic World (2 vols), Edited by Salma K. Jayyusi, Renata Holod, Attilio Petruccioli and André Raymond

Whyte, W. H. (1980) The Social Life of Small Urban Spaces, Project for Public Spaces, New York 
Yin, R. K. (1995), Case Study Research, Design and Methods, Sage Publications, Thousands Oaks, London, New Delhi

\section{SCIENTIFIC JOURNALS}

Acun Fatma, A portrait of the Ottoman Cities, Muslim Worls 92, no 3/4 Fall 2002, The H.W Wilson Company

Çaha Ö., Karaman, Lutfullah M. Civil Society in the Ottoman Empire, Journal of Economic Research 8(2), 53-81, 2008

Cerasi, Maurice M. Open Space, Water and Trees in Ottoman Urban Culture in the XVIIIth - XIXth Centuries in Environmental Design: Journal of the Islamic Environmental Design Research Centre 2, edited by AttiloPetruccioli, 36-50. Rome: Carucci Editions, 1985

Cerasi, Maurice. Frenk, Hind ve Sind: Real or Imaginary in the Aesthetics of Ottoman Open Spaces, in Environmental Design: Journal of the Islamic Environmental Design Research Centre 2, edited by AttiloPetruccioli, 16-23. Rome: Carucci Editions, 1986.

Evyapan, G. A., (1972), Anatolian Turkish Gardens, Journal of the Faculty of Architecture, Volume 1, METU, Ankara

Habermas, J; Lennox, S.; Ldnnox, F., (1964), New German Critique The Public Sphere: An Encyclopedia Article, No. 3. (Autumn, 1974), pp. 49-55.

Jalaladdini, S. and Oktay, D. (2011) Urban Public Spaces and Vitality: A Socio-Spatial Analysis in the Streets of Cypriot Towns, Procedia - Social and Behavioral Sciences 35 ( 2012 ) $664-674$ (2011)

Montgomery, J. (1998) Making a city: urbanity, vitality and urban design, Journal of Urban Design, 3: 1, 93-116.

\section{RESEARCH REPORTS}

CHwB (2015) Historic Urban Area - Framework for the regeneration of the Grand Gjakova Bazaar, Prishtina/Gjakova 


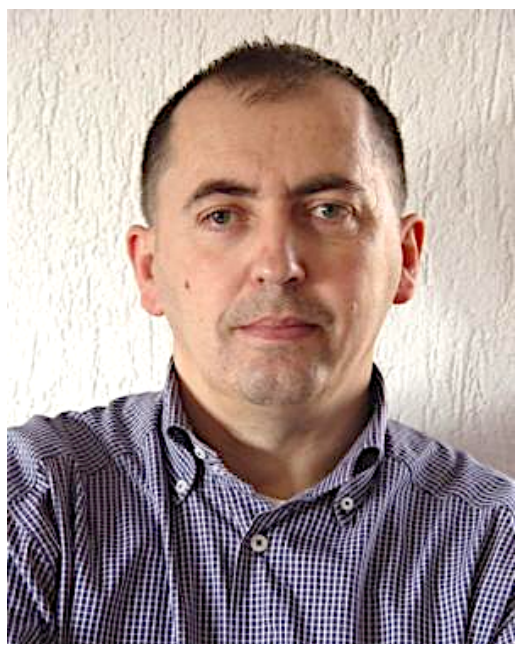

Ilir GJINOLLI (1962) Graduated at the Department of Architecture at Prishtina University in 1986. Between 19881991 was enrolled in the master studies at the faculty of Architecture, Zagreb University. In 1988, he started academic carrier as a teaching assistant of Urban Design at the University of Prishtina, Department of Architecture. From 1991 he works as a lecturer of urbanism. In 2016 he completed his PhD studies at the Faculty of Architecture, Graz University of Technology, with the thesis 'Public Space in Kosovo-Transformation through History'.

He is one of the founders of the Department of Spatial Planning within the Ministry of Environment and Spatial Planning of Kosovo in 2002. In 2003, with the support of UN Habitat, he initiated the establishment of the Institute of Spatial Planning and was director until 2006. He was team leader of the Spatial Plan for Kosovo 2006-2016.

In 2001 established multidisciplinary studio of architecture and urban design URBAN PLUS in Prishtina, where he works as director from 2006. During this period, he worked in many planning projects including Municipal Development Plan of Suhareka as a local partner of the Institute for Regional Planning and Regional Development, TU Vienna.

In 2010, together with Alfredo Navarro, a Spanish architect, established EUROPAN Kosovo, a local organisation under EUROPAN Europe, which organises EUROPAN, a European architectural competition dedicated to architects under 40 's. He is president of the local organization 